Arab culture 61

Ataxia telangiectasia 12

Autosomal recessive disorders 21, 27

Bahrain, genetic blood diseases 52

Bedouin 21

Birth prevalence, autosomal recessive diseases 27

Childhood shyness 61

Clinical genetics 7

Complex diseases, Oman 56

Consanguinity $17,21,35,48,56$

Developing/developed countries 12

DNA diagnostics, Kuwait 40

Endogamy 17

Funding, genetic health care 12

Genetic communities 7

- counseling 31, 48

- epidemiology 12

Global health care 12

Gross domestic product 12

Health care insurance 12

Homozygosity 17, 21
Inherited metabolic diseases 44

Isolates, genetic 21

Kuwait, DNA diagnostics 40

Lethal malformations 31

Middle East, genetic diseases 21, 44

Neonates, lethal malformations 31

Oman, autosomal recessive diseases 27

-, family study 56

Premarital counseling 52

Prevalence, genetic blood diseases 52

Public health 7

\section{Retinoblastoma 12}

Sickle cell anemia 52

Social phobia 61

$\beta$-Thalassemia 35,52

Wahlund effect 17

\section{KARGER}

(C) 2005 S. Karger AG, Base

Fax +41613061234

E-Mail karger@karger.ch

www.karger.com
Accessible online at: www. karger.com/cmg 